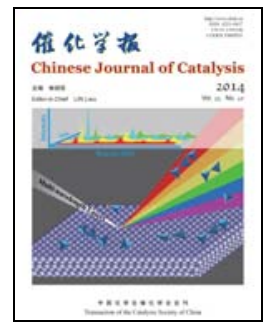

Article

\title{
Synthesis of mesoporous ZSM-5 using a new gemini surfactant as a mesoporous directing agent: A crystallization transformation process
}

\author{
Quanyi Wanga,b,e, Yingxu Wei a,*, Shutao Xua , Mozhi Zhanga,e, Shuanghe Menga, Dong Fan a,e, \\ Yue Qi a , Jinzhe Li a, Zhengxi Yua, Cuiyu Yuan a, Yanli Hea, Shuliang Xua ${ }^{a}$, Jingrun Chen a,e, \\ Jinbang Wanga , Baolian Su b,c,\#, Zhongmin Liu ${ }^{\text {a,d,§ }}$ \\ a Dalian National Laboratory for Clean Energy, Dalian Institute of Chemical Physics, Chinese Academy of Sciences, Dalian 116023, Liaoning, China \\ ${ }^{\mathrm{b}}$ Laboratory of Inorganic Materials Chemistry (CMI), University of Namur (FUNDP), 61 rue de Bruxelles, B-5000 Namur, Belgium \\ c State key Laboratory of Advanced Technology for Materials Synthesis and Processing, Wuhan University of Technology, Wuhan 430070, Hubei, China \\ d State Key Laboratory of Catalysis, Dalian Institute of Chemical Physics, Chinese Academy of Sciences, Dalian 116023, Liaoning, China \\ e University of Chinese Academy of Sciences, Beijing 100049, China
}

A R T I C L E I N F O

\section{Article history:}

Received 9 April 2014

Accepted 28 May 2014

Published 20 October 2014

\section{Keywords:}

Mesoporous ZSM-5

Dual-templating

Gemini surfactant

Inter-crystalline mesopore

Crystallization transformation

\begin{abstract}
A B S T R A C T
A new gemini surfactant, $\left[\mathrm{C}_{18} \mathrm{H}_{37}\left(\mathrm{CH}_{3}\right)_{2}-\mathrm{N}^{+}-\left(\mathrm{CH}_{2}\right)_{3}-\mathrm{N}^{+}-\left(\mathrm{CH}_{3}\right)_{2} \mathrm{C}_{18} \mathrm{H}_{37}\right] \mathrm{Cl}_{2}\left(\mathrm{C}_{18-3-18}\right)$, has been successfully used as the mesopore directing agent in the hydrothermal synthesis of mesoporous ZSM-5 (MZSM-5). The synthesis of MZSM-5 was realized with a low temperature crystallization process at $130{ }^{\circ} \mathrm{C}$. The amount of $\mathrm{C}_{18-3-18}$ used in the synthesis affected the relative crystallinity and the textural properties of the obtained MZSM-5. Detailed investigation showed that the formation of MZSM-5 followed a crystallization transformation process. The use of $\mathrm{C}_{18-3-18}$ resulted in the formation of mesoporous material during the early stage of the synthesis, which was converted into MZSM-5 crystals templated by tetrapropylammonium bromide to form the MFI phase. As the synthesis proceeded, the MZSM- 5 crystals aggregated into particles by weak interactions. This work shows that $\mathrm{C}_{18-3-18}$ can be used as a mesopore directing agent, which could provide a route for the synthesis of other mesoporous zeolites.
\end{abstract}

(C) 2014, Dalian Institute of Chemical Physics, Chinese Academy of Sciences. Published by Elsevier B.V. All rights reserved.

\section{Introduction}

Mesoporous ZSM-5 (MZSM-5), normally referred to ZSM-5 with both micropore and mesopore systems, is supposed to combine the benefits of each separate pore size regime and has great potential to improve the efficiency of zeolite catalysis, enhance the accessibility to active sites, and reduce the diffusion obstacle [1-4]. Therefore, considerable efforts have fo- cused on the synthesis of MZSM-5.

A wide variety of synthesis strategies have been proposed to create mesopores in ZSM-5 crystals. Various post-treatment methods, including heat treatment [5], acid leaching [6-8], steaming treatment [6,7], alkaline leaching $[9,10]$, and other chemical treatments [11], have proven to be efficient in creating mesopores in ZSM-5 crystals. Another strategy for the synthesis of ZSM-5 crystals containing mesopores is crystallization

\footnotetext{
* Corresponding author. Tel: 86-411-84379335; Fax: 86-411-84691570; E-mail: weiyx@dicp.ac.cn

\# Corresponding Author. E-mail: bao-lian.su@unamur.be, baoliansu@whut.edu.cn

§ Corresponding author. Tel: 86-411-84379335; Fax: 86-411-84691570; E-mail: liuzm@dicp.ac.cn

This work was supported by the National Natural Science Foundation of China $(21273230,21273005,21103176,21103180)$.

DOI: 10.1016/S1872-2067(14)60128-5 | http://www.sciencedirect.com/science/journal/18722067 | Chin. J. Catal., Vol. 35, No. 10, October 2014
} 
using a dual-templating method, which includes both ZSM-5 templates and mesopore structure directing agents. In the dual-templating method, both hard templates, such as carbon nanoparticles or nanotubes [12,13], poly(methyl methacrylate) (PMMA) nanospheres [14], nano $\mathrm{CaCO}_{3}$ [15], and polymer beads [16], and soft templates, such as cationic surfactants (CTABs) [17,18], nonionic alkyl poly(ethylene oxide) surfactants [19], organosiliane [20], cationic polymer [21], silylated polymer [22], and natural products [23], have attracted considerable attention because of their high efficiency in creating mesopores in ZSM-5. Recently, Ryoo et al. [24-26] made progress in synthesizing MZSM-5 using an organic surfactant equipped with a multi-ammonium headgroup, which could serve as both a zeolitic template and a mesogenous structure directing agent. Synthesis methods involving the development of new surfactants for mesoporous zeolite synthesis are still of interest in the field of hierarchical materials.

In this study, we report a facile and highly efficient synthesis route to prepare MZSM-5 using a new gemini surfactant, $\left[\mathrm{C}_{18} \mathrm{H}_{37}\left(\mathrm{CH}_{3}\right)_{2}-\mathrm{N}^{+}-\left(\mathrm{CH}_{2}\right)_{3}-\mathrm{N}^{+}-\left(\mathrm{CH}_{3}\right)_{2} \mathrm{C}_{18} \mathrm{H}_{37}\right] \mathrm{Cl}_{2}\left(\mathrm{C}_{18-3-18}\right)$, as the mesopore directing agent. Scheme 1 shows the structure model of $\mathrm{C}_{18-3-18}$. To the best of our knowledge, the synthesis of MZSM-5 using $\mathrm{C}_{18-3-18}$ as the mesopore directing agent has not been reported. The formation mechanism of MZSM-5 templated from $\mathrm{C}_{18-3-18}$ is also discussed based on experimental observations.

\section{Experimental}

\subsection{Chemicals and synthesis}

All of the chemical reagents in this article $\left(\mathrm{NaAlO}_{2}\right.$ (41 wt\% $\mathrm{Al}_{2} \mathrm{O}_{3}$ ), tetraethyl orthosilicate (TEOS, 98.0\%,), tetrapropylammonium bromide (TPABr, 98.0\%), $\mathrm{NaOH}$ (96.0\%), and $\mathrm{C}_{18-3-18}(95.0 \%)$ ) were commercial products of analytical grade, and were used as received without further purification.

The MZSM-5 samples were synthesized with the hydrothermal method using $\mathrm{C}_{18-3-18}$ as the mesogenous template and a gel with the molar composition of $40 \mathrm{SiO}_{2}: 1 \mathrm{Al}_{2} \mathrm{O}_{3}: 20 \mathrm{NaOH}$ : 10 TPABr: $x$ C18-3-18:7000 $\mathrm{H}_{2} \mathrm{O}$ with different crystallization temperatures and times. In a typical synthesis procedure, 0.26 $\mathrm{g} \mathrm{NaAlO}_{2}, 0.80 \mathrm{~g} \mathrm{NaOH}$, and $2.80 \mathrm{~g}$ TPABr were dissolved in 135 $\mathrm{g} \mathrm{H}_{2} \mathrm{O}$. Then, $8.93 \mathrm{~g}$ TEOS and $3.33 \mathrm{~g} \mathrm{C}_{18-3-18}$ (here, $x=4$ ) were added into the synthesis gel under agitation. After mixing, the synthesis gel was transferred into a $200 \mathrm{~mL}$ Teflon-lined stainless steel pressure vessel, sealed, and heated under autogenic pressure with vigorous stirring. After crystallization, the as-synthesized sample was centrifugally separated, washed, dried at $120^{\circ} \mathrm{C}$ for $12 \mathrm{~h}$, and calcined at $600{ }^{\circ} \mathrm{C}$ for $6 \mathrm{~h}$. Herein, the sample synthesized at $150{ }^{\circ} \mathrm{C}$ for $36 \mathrm{~h}$ is denoted MZSM-5-A, the sample synthesized at $130{ }^{\circ} \mathrm{C}$ for $120 \mathrm{~h}$ is de-

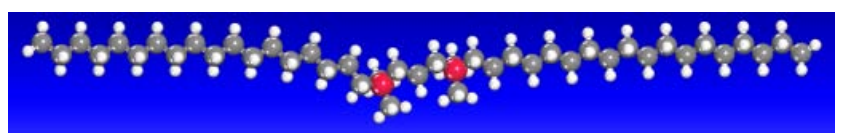

Scheme 1. Structure model of $\left[\mathrm{C}_{18} \mathrm{H}_{37}\left(\mathrm{CH}_{3}\right)_{2}-\mathrm{N}^{+}-\left(\mathrm{CH}_{2}\right)_{3}-\mathrm{N}^{+}-\left(\mathrm{CH}_{3}\right)_{2}-\right.$ $\left.\mathrm{C}_{18} \mathrm{H}_{37}\right] \mathrm{Cl}_{2}$. noted MZSM-5-B, and the sample first synthesized at $120^{\circ} \mathrm{C}$ for $48 \mathrm{~h}$ and then at $175^{\circ} \mathrm{C}$ for $6 \mathrm{~h}$ is denoted MZSM-5-C. For comparison, conventional ZSM-5 was also synthesized starting from the synthesis gel with the same composition but without adding $\mathrm{C}_{18-3-18}$, and this sample is referred to as ZSM-5. The crystallization conditions of ZSM- 5 were $175^{\circ} \mathrm{C}$ for $48 \mathrm{~h}$.

\subsection{Characterization}

X-ray diffraction (XRD) patterns were obtained with a $\mathrm{D} /$ max-rb X-ray diffractometer, using $\mathrm{Cu} K_{\alpha}$ radiation $(\lambda=$ $1.5405 \AA$ ) at room temperature with instrumental settings of $40 \mathrm{kV}$ and $40 \mathrm{~mA}$. The relative crystallinity was calculated based on the intensity of the five peaks with $2 \theta=22^{\circ}-25^{\circ}$.

Scanning electron microscopy (SEM) images were obtained for morphological identification using a KYKY AMRAY-1000B scanning microscope. Transmission electron microscopy (TEM) images were obtained with a JEOL JEM-2000Ex electron microscope at $120 \mathrm{kV}$.

$\mathrm{N}_{2}$ adsorption-desorption experiments were performed at $-196{ }^{\circ} \mathrm{C}$ on a NOVA 4000 gas adsorption analyzer (Quantachrome Corp.). Each sample was evacuated at $130{ }^{\circ} \mathrm{C}$ for $1 \mathrm{~h}$ and then at $350^{\circ} \mathrm{C}$ for $3 \mathrm{~h}$ before adsorption.

${ }^{27} \mathrm{Al}$ magic angle spinning (MAS) nuclear magnetic resonance (NMR) measurements were performed on a $600 \mathrm{MHz}$ Bruker Avance III equipped with a $4 \mathrm{~mm}$ MAS probe. ${ }^{27} \mathrm{Al}$ MAS NMR spectra were recorded using one pulse sequence with a spinning rate of $12 \mathrm{kHz} .100$ scans were accumulated with a $\pi / 8$ pulse width of $0.75 \mu$ s and a 2 s recycle delay. The chemical shifts were referenced to $\left(\mathrm{NH}_{4}\right) \mathrm{Al}\left(\mathrm{SO}_{4}\right)_{2} \cdot 12 \mathrm{H}_{2} \mathrm{O}$ at $-0.4 \mathrm{ppm}$.

\section{Results and discussion}

\subsection{Synthesis at different crystallization temperatures}

The XRD patterns of the samples synthesized using different crystallization temperature routes are shown in Fig. 1 and compared with the XRD pattern of conventional ZSM-5. The intrinsic lattice structure of the MFI topology was observed for all samples, and no other phases were formed during the syn-

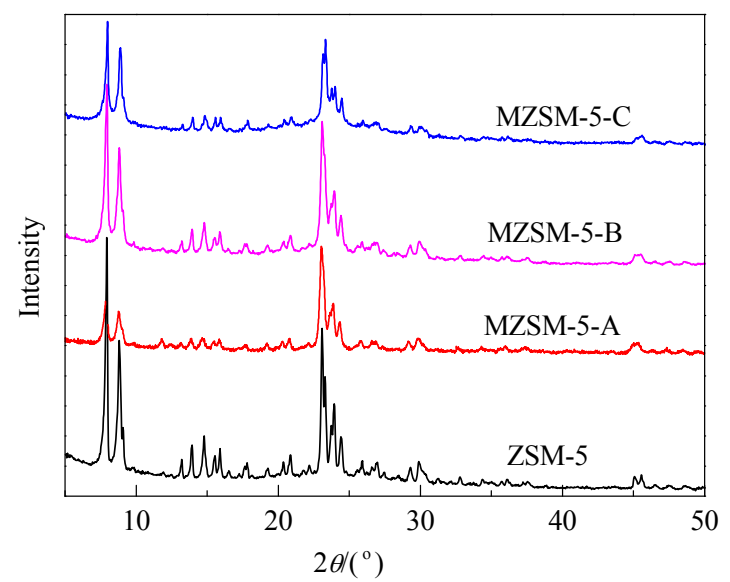

Fig. 1. XRD patterns of ZSM-5 and the MZSM-5 samples synthesized at different crystallization temperatures. 
thesis. Furthermore, even starting from the gel with the same composition using dual templates (TPABr and $\mathrm{C}_{18-3-18}$ ) there was still some difference in the relative crystallinity of the synthesized MZSM-5 samples, which can be attributed to the different crystallization temperatures. Among the three MZSM-5 samples, MZSM-5-A and MZSM-5-C had low relative crystallinity. MZSM-5-B had the highest relative crystallinity and very close to that of conventional ZSM-5, indicating that the crystallization procedure for MZSM-5-B $\left(130^{\circ} \mathrm{C}\right.$ for $\left.120 \mathrm{~h}\right)$ had the optimal conditions for the synthesis of MZSM-5.

The $\mathrm{N}_{2}$ adsorption-desorption isotherms of ZSM-5 and the MZSM-5 samples are shown in Fig. 2(a). The curves of the pore size distribution, which were calculated from the adsorption branches using the BJH model, are shown in Fig. 2(b). As shown in Fig. 2(a), ZSM-5 shows a representative Type I (Langmuir) isotherm according to the classification of IUPAC, with no obvious increase in the adsorbed $\mathrm{N}_{2}$ amount and no distinct hysteresis loop at high relative pressure, which is characteristic of microporous materials with no mesoporosity. This is verified by the BJH pore size distribution curve of ZSM-5 (Fig. 2(b)), where there is no obvious peak in the mesoporous range, indicating only microporosity in ZSM-5. As listed in Table 1, the BET surface area and total pore volume of ZSM-5 are $328 \mathrm{~m}^{2} / \mathrm{g}$ and $0.16 \mathrm{~cm}^{3} / \mathrm{g}$, while the mesoporous surface area and pore volume are very low, only $59 \mathrm{~m}^{2} / \mathrm{g}$ and $0.03 \mathrm{~cm}^{3} / \mathrm{g}$, respectively.

For the MZSM-5 samples, the $\mathrm{N}_{2}$ adsorption-desorption isotherms are greatly different from that of conventional ZSM-5. As shown in Fig. 2(a), the $\mathrm{N}_{2}$ adsorption-desorption isotherms of the MZSM-5 samples are mixed Type I and Type IV isotherms, indicating the existence of both microporosity and mesoporosity in the three samples (MZSM-5-A, MZSM-5-B, and MZSM-5-C) synthesized by the dual-templating method at different crystallization temperatures. The other important features include a dramatic increase in the adsorption amounts at high relative pressure compared with the conventional ZSM-5 isotherm. In addition, a hysteresis loop confirms the generation of mesopores. Because of the generation of mesopores in the three samples, their mesoporous surface areas and mesopo-

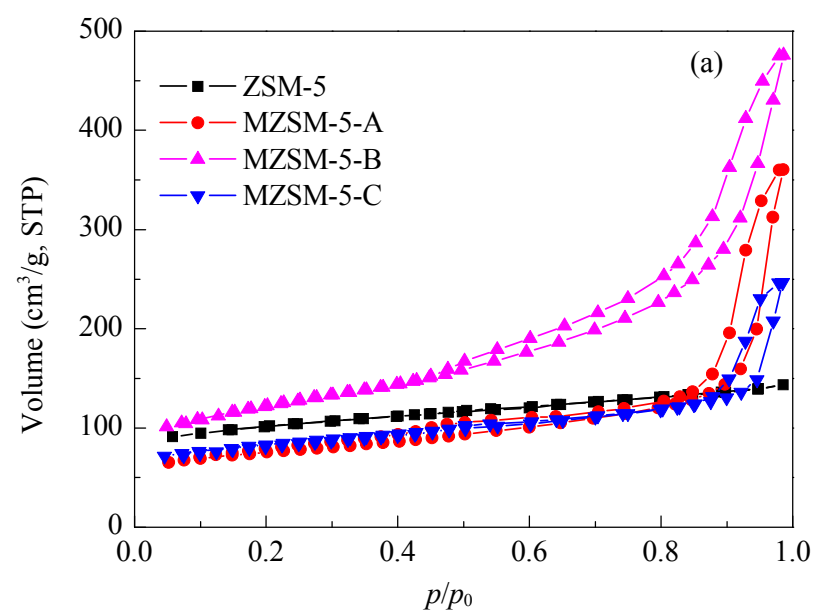

Table 1

Textural properties of conventional ZSM-5 and the MZSM-5 samples synthesized at different crystallization temperatures.

\begin{tabular}{lccccccc}
\hline \multirow{2}{*}{ Sample } & \multicolumn{3}{c}{ Surface area $\left(\mathrm{m}^{2} / \mathrm{g}\right)$} & & \multicolumn{3}{c}{ Pore volume $\left(\mathrm{cm}^{3} / \mathrm{g}\right)$} \\
\cline { 2 - 4 } \cline { 6 - 8 } & $S_{\text {BET }}$ & $S_{\text {Meso }}$ & $S_{\text {Micro }}$ & & $V_{\text {total }}$ & $V_{\text {Meso }}$ & $V_{\text {Micro }}$ \\
\hline ZSM-5 & 328 & 59 & 269 & & 0.16 & 0.03 & 0.13 \\
MZSM-5-A & 254 & 133 & 121 & & 0.55 & 0.49 & 0.06 \\
MZSM-5-B & 418 & 268 & 150 & & 0.73 & 0.66 & 0.07 \\
MZSM-5-C & 279 & 141 & 138 & & 0.38 & 0.32 & 0.06 \\
\hline
\end{tabular}

rous volumes are larger than those of ZSM-5. However, the increase in mesoporosity of the MZSM-5 samples is accompanied with a decrease of microporosity (Table 1). The pore size distributions of the MZSM-5 samples calculated from the adsorption branches using the $\mathrm{BJH}$ model show a wide range of pore sizes, which suggests the possible generation of inter-crystalline mesopores. As shown in Fig. 2(b), the mesopore sizes of MZSM-5-A, MZSM-5-B, and MZSM-5-C vary from 2 to $100 \mathrm{~nm}$. Most of the mesopores in MZSM-5-A and MZSM-5-C are around $50 \mathrm{~nm}$, while the peak of mesopores around $50 \mathrm{~nm}$ in MZSM-5-B is relatively low intensity. However, the number of mesopores in the range 2 to $10 \mathrm{~nm}$ is significantly larger for MZSM-5-B than for MZSM-5-B and MZSM-5-C.

The representative SEM images of ZSM-5 and the MZSM-5 samples are given in Fig. 3. Microporous ZSM-5 appears to be composed of crystals with different sizes from 0.6 to $1 \mu \mathrm{m}$. MZSM-5-A is also composed of crystals of different sizes. The larger crystals with a size of $\sim 10 \mu \mathrm{m}$ seem to be the aggregation of smaller crystals of $\sim 1 \mu \mathrm{m}$. As shown in Fig. 3(e), MZSM-5-B is composed of different sized particles, and its enlarged image (Fig. 3(f)) shows that the grainy surface of MZSM-5-B is the aggregation of many small ZSM-5 crystals. In addition, it should be mentioned that the aggregation of ZSM-5 crystals into particles can induce the formation of some inter-crystalline mesopores in MZSM-5-B, which can be seen in Fig. 3(f). This result is consistent with the $\mathrm{N}_{2}$ physical adsorption measurement. Correspondingly, Fig. 3(g) and (h) indicate that MZSM-5-C, like MZSM-5-A and MZSM-5-B, is composed of different sized particles, which are composed of small ZSM-5 crystals. Among the three MZSM-5 samples, MZSM-5-B has a

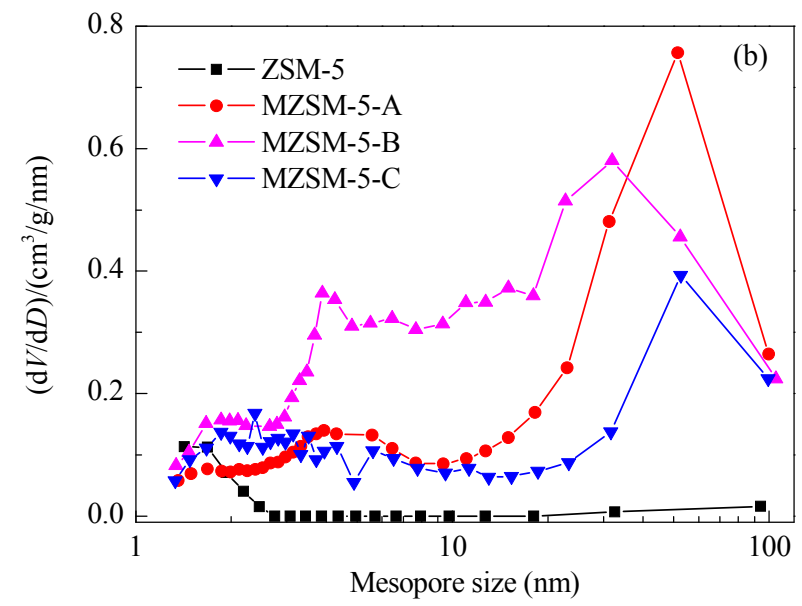

Fig. 2. $\mathrm{N}_{2}$ adsorption-desorption isotherms (a) and pore size distributions (b) of conventional ZSM-5 and the MZSM-5 samples synthesized at different crystallization temperatures. 

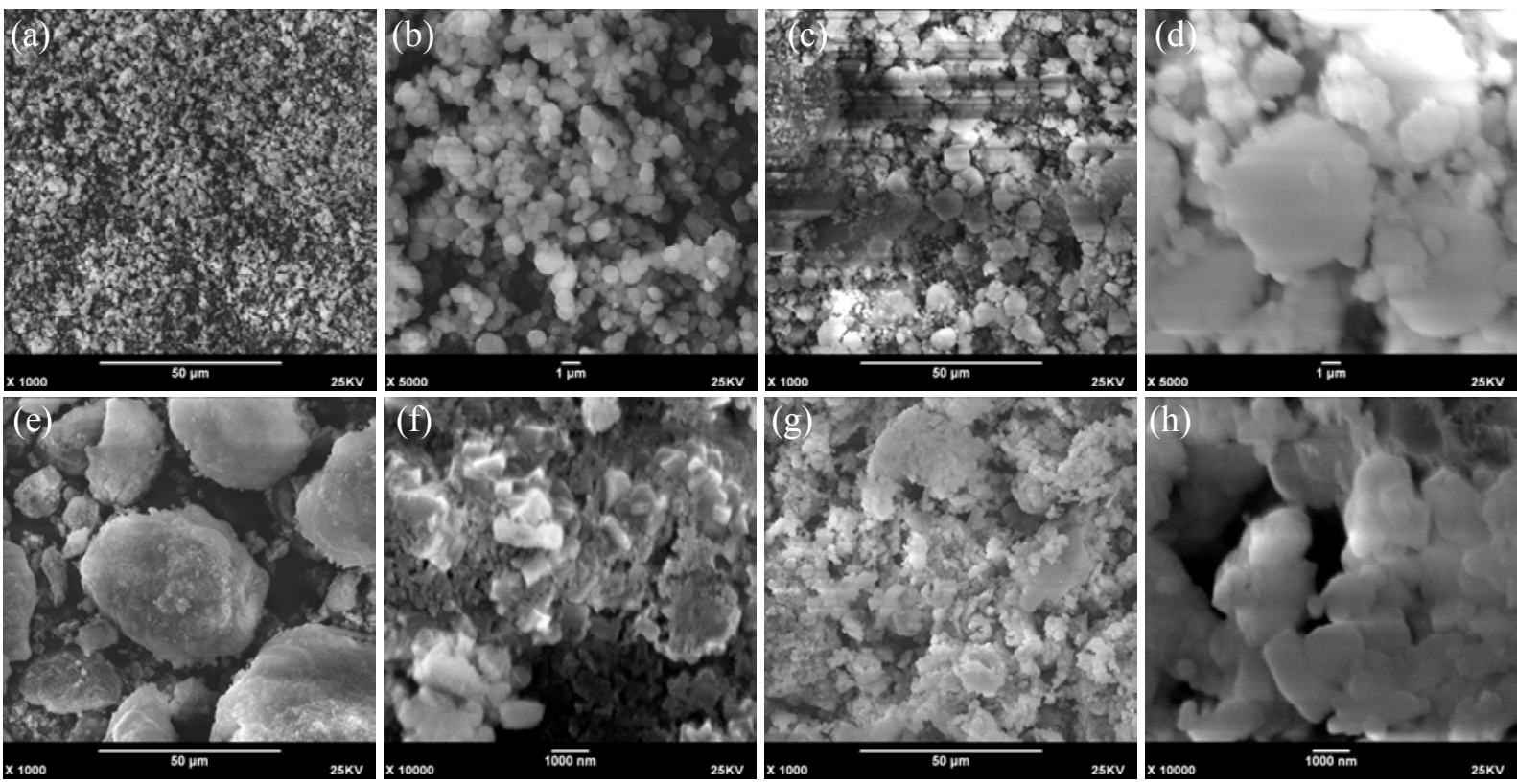

Fig. 3. SEM images of ZSM-5 and the MZSM-5 samples synthesized at different crystallization temperatures. (a) ZSM-5; (b) Enlargement of (a); (c) MZSM-5-A; (d) Enlargement of (c); (e) MZSM-5-B; (f) Enlargement of (e); (g) MZSM-5-C; (h) Enlargement of (g).

more regular morphology, which may result from the relatively low crystallization temperature.

Based on the characterizations mentioned above, it can be concluded that the different crystallization routes carried out at different temperatures affect the morphology and the textural properties of synthesized MZSM-5. A relatively low crystalline temperature, such as $130{ }^{\circ} \mathrm{C}$, seems to be the optimal crystallization temperature for the synthesis of MZSM-5 with high mesoporous surface area, high mesoporous volume, and regular morphology, as well as good relative crystallinity from the formation of the MFI phase during the synthesis. The relatively low crystallization temperature required to synthesize MZSM-5 using $\mathrm{C}_{18-3-18}$ as a mesopore directing agent may originate from its unique $-\mathrm{N}^{+}-\left(\mathrm{CH}_{2}\right)_{3}-\mathrm{N}^{+}-$group, which still needs further investigation.

\subsection{Effect of the amount of $C_{18-3-18}$}

The amount of mesoporous structure directing agent usually affects the relative crystallinity, morphology, and textural properties of the synthesized MZSM-5. Thus, the effect of the amount of $\mathrm{C}_{18-3-18}$ was also investigated in the MZSM-5 synthesis following the optimized crystallization route confirmed in Section 3.1 (crystallization at $130{ }^{\circ} \mathrm{C}$ for $96 \mathrm{~h}$ ). The molar composition of the starting gel was $40 \mathrm{SiO}_{2}: 1 \mathrm{Al}_{2} \mathrm{O}_{3}: 20 \mathrm{NaOH}: 10$ TPABr: $x$ C18-3-18:7000 $\mathrm{H}_{2} \mathrm{O}$, in which $x$ represents the amount of $\mathrm{C}_{18-3-18}$ used in the synthesis gel.

The XRD patterns of the samples synthesized using different amounts of $\mathrm{C}_{18-3-18}$ are shown in Fig. 4. Even varying the amount of mesoporous structure directing agent, the intrinsic lattice structure of the MFI topology was identified for all four samples, and no other phases were formed during the synthesis of the MZSM-5 samples. Furthermore, when $\mathrm{C}_{18-3-18}$ was added in amounts of $x=2$ and 4 , there was almost no difference in the relative crystallinity of the two synthesized MZSM-5 samples. When more $\mathrm{C}_{18-3-18}$ was added $(x=6)$, the relative crystallinity of the synthesized MZSM-5 structure was higher than with $x=2$ or 4 . Further increasing the amount of $\mathrm{C}_{18-3-18}(x$ $=8$ ) resulted in a decrease of the relative crystallinity of the synthesized MZSM-5 sample compared with $x=6$. This is usually observed during the synthesis of MZSM-5 using the dual-templating method. Under most circumstances, the two different templating systems, i.e., the ZSM-5 structure directing agent (TPABr) and the mesoporous template $\left(\mathrm{C}_{18-3-18}\right)$, work in a competitive rather than a cooperative manner. If too much $\mathrm{C}_{18-3-18}$ is added into the synthesis gel, even though the mesoporous phase can be generated, the very slow formation of the MFI phase results in it being difficult to transform the generated mesoporous phase to crystallized ZSM-5. Therefore, more of the mesoporous phase remains, which results in a low relative crystallinity.

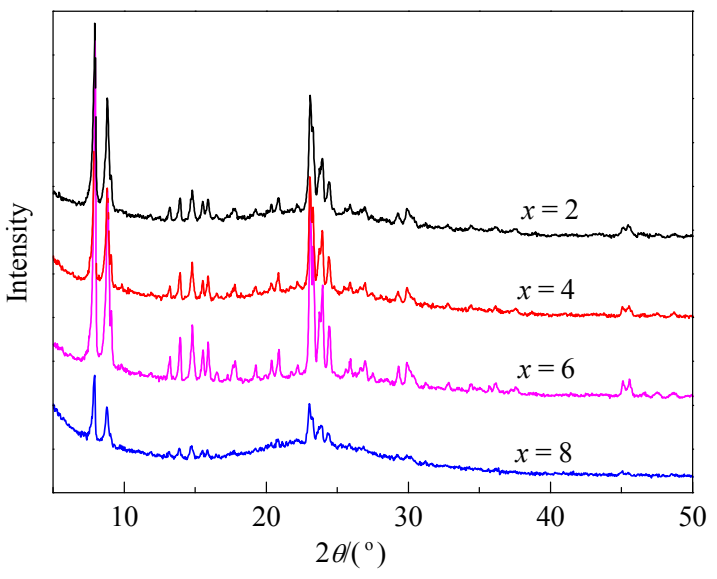

Fig. 4. XRD patterns of the MZSM-5 samples synthesized using different amounts of $\mathrm{C}_{18-3-18 .}$ 

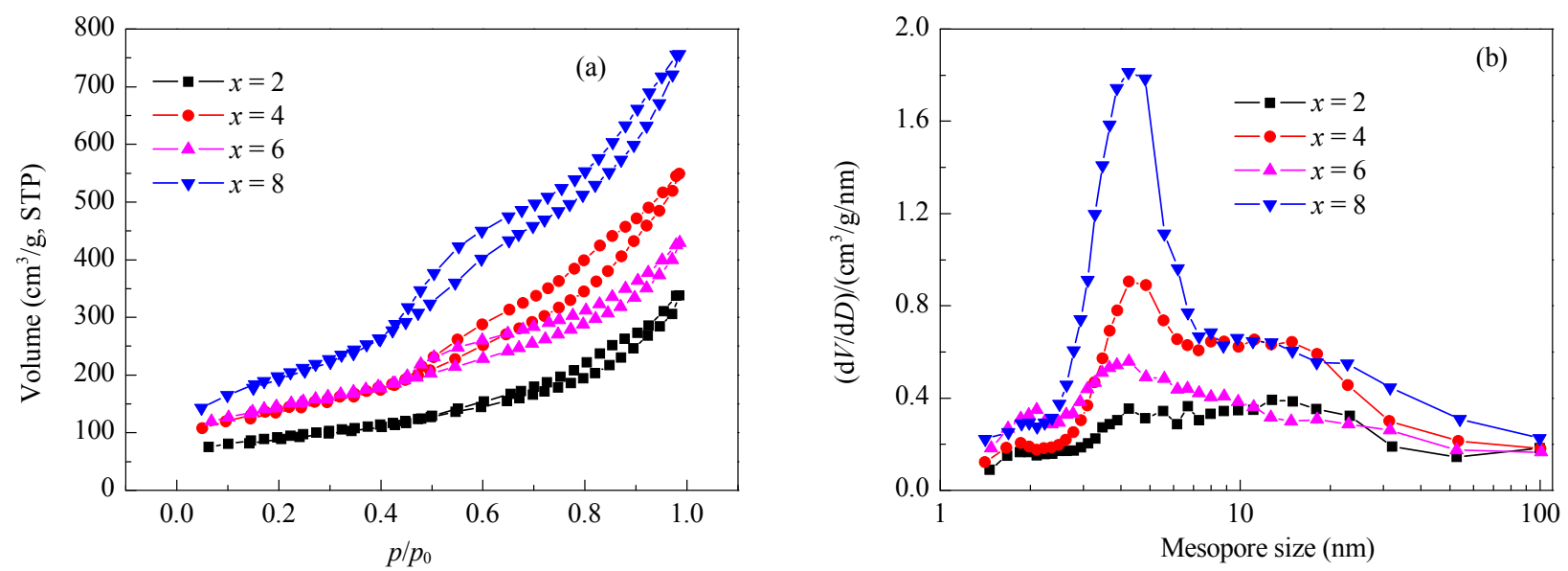

Fig. 5. $\mathrm{N}_{2}$ adsorption-desorption isotherms (a) and pore size distributions (b) of the MZSM-5 samples synthesized using different amounts of $\mathrm{C}_{18-3-18}$.

The $\mathrm{N}_{2}$ adsorption-desorption isotherms, the pore size distribution curves, and textual properties of the samples synthesized using different amounts of $\mathrm{C}_{18-3-18}$ are shown in Fig. 5 and Table 2. As shown in Fig. $5 \mathrm{a}$, all of the $\mathrm{N}_{2}$ adsorption and desorption isotherms of the MZSM-5 samples are mixed Type I and Type IV isotherms, indicating the coexistence of micropores and mesopores. With increasing added amount of C18-3-18 from $x=2$ to 6 , the total surface area ( $S_{\text {BET }}$ ) increased from $325 \mathrm{~m}^{2} / \mathrm{g}$ to $515 \mathrm{~m}^{2} / \mathrm{g}$. Among the three samples, the total pore volume of the sample synthesized with $x=4\left(0.82 \mathrm{~cm}^{3} / \mathrm{g}\right)$ was higher than the other two samples $\left(0.52 \mathrm{~cm}^{3} / \mathrm{g}\right.$ for $x=2$ and $0.66 \mathrm{~cm}^{3} / \mathrm{g}$ for $x=6$ ), which may stem from its rich mesoporosity. The relatively low pore volume of the sample synthesized with $x=6$ can be explained by the generation of more micropores, resulting in the loss of mesopores. Further increasing the amount of $\mathrm{C}_{18-3-18}$ to $x=8$, resulted in the obtained MZSM-5 having the highest surface area and pore volume among the four samples, which is because of the generation of a highly mesoporous structure. However, considering its very low relative crystallinity and microporous surface area, the addition of too much of the mesopore directing agent is not beneficial for the generation of MZSM-5.

The abovementioned results indicate that under the present experimental conditions, the addition of a moderate amount of C18-3-18 during the synthesis ( $x=4$ and 6 ) favors the synthesis of MZSM-5 with good relative crystallinity and relatively good mesopore generation.

The pore size distributions of the four MZSM-5 samples (Fig. $5(b))$ indicate that the generated mesopores have a wide range of sizes (2-30 nm) when adding a moderate amount of $\mathrm{C}_{18-3-18}$ $(x=2,4$, and 6) into the synthesis gel. Increasing the amount of

Table 2

Textural properties of the MSM-5 samples synthesized using different amounts of $\mathrm{C}_{18-3-18 \text {. }}$

\begin{tabular}{llllllll}
\hline C18-3-18 & \multicolumn{3}{c}{ Surface area $\left(\mathrm{m}^{2} / \mathrm{g}\right)$} & & \multicolumn{3}{c}{ Pore volume $\left(\mathrm{cm}^{3} / \mathrm{g}\right)$} \\
\cline { 2 - 3 } \cline { 7 - 8 } amount & $S_{\text {BET }}$ & $S_{\text {Meso }}$ & $S_{\text {Micro }}$ & & $V_{\text {total }}$ & $V_{\text {Meso }}$ & $V_{\text {Micro }}$ \\
\hline$x=2$ & 325 & 253 & 72 & & 0.52 & 0.49 & 0.03 \\
$x=4$ & 491 & 389 & 102 & & 0.82 & 0.78 & 0.04 \\
$x=6$ & 515 & 405 & 110 & & 0.66 & 0.61 & 0.05 \\
$x=8$ & 720 & 698 & 22 & & 1.16 & 1.15 & 0.01 \\
\hline
\end{tabular}

$\mathrm{C}_{18-3-18}$ to $x=8$ results in the generated mesopores having a narrow size range centered at $4 \mathrm{~nm}$.

\subsection{Formation process of MZSM-5}

To investigate the formation process of MZSM-5, the synthesis was carried out for different crystallization times using the same amount of $\mathrm{C}_{18-3-18}(x=4)$ at $130{ }^{\circ} \mathrm{C}$. Samples were synthesized and characterized for crystallization times of 8, 24, 48, 72, 96, and $120 \mathrm{~h}$. The samples synthesized for 96 and 120 $\mathrm{h}$ have been mentioned above, the sample with $x=4$ in Section 3.2 and MZSM-5-B in Section 3.1.

The small-angle and the wide-angle powder XRD patterns of the samples synthesized for different crystallization times are shown in Fig. 6. When the synthesis was performed for 8 or 24 $\mathrm{h}$, no diffraction peaks are present in the wide-angle powder XRD pattern of the solid samples. However, a peak is present in their small-angle powder XRD patterns, suggesting the two
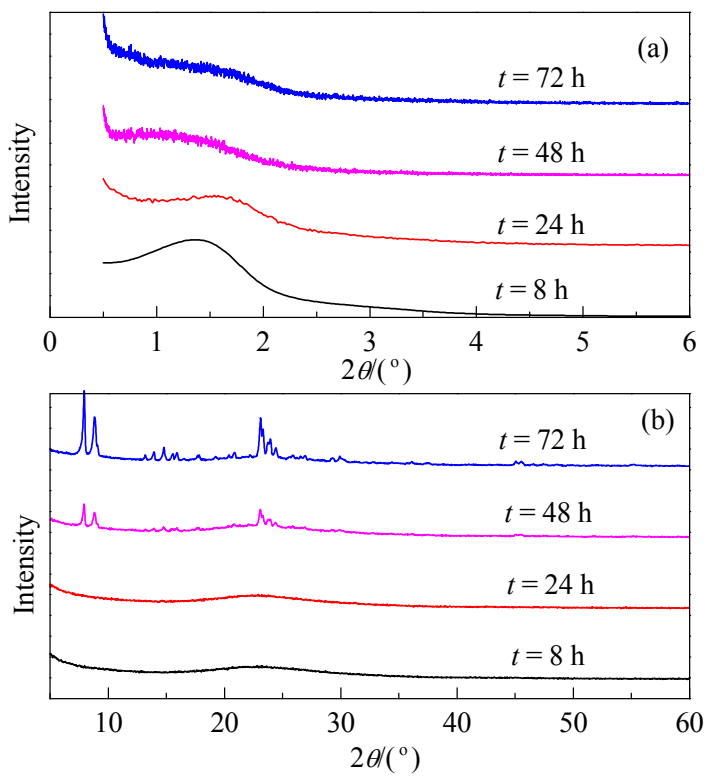

Fig. 6. Small-angle (a) and wide-angle (b) powder XRD patterns of samples synthesized for different crystallization times. 


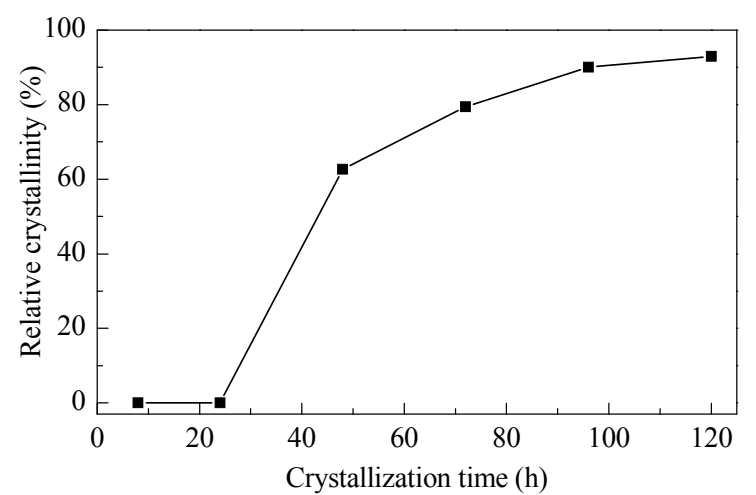

Fig. 7. Crystallization curve of MZSM-5 synthesized at $130^{\circ} \mathrm{C}$.

samples are mesoporous materials. For the samples synthesized for more than $24 \mathrm{~h}, \mathrm{ZSM}-5$ is detected as the only crystalline phase during the crystallization process. This indicates the slow crystallization character of ZSM-5 under the given experimental conditions, in which an induction period in the early stage is required for the crystallization process. Diffraction peaks of ZSM-5 become evident after crystallization for $48 \mathrm{~h}$, and the intensity of the peaks greatly increases when increasing the crystallization time to $72 \mathrm{~h}$.

The crystallization curve based on the relative crystallinity calculated from Fig. 6 is shown in Fig. 7. The reference sample used here is conventional ZSM-5, whose relative crystallinity was defined as $100 \%$. During the initial $24 \mathrm{~h}$, there is an induction period and no ZSM-5 phase forms. For a crystallization time of $48 \mathrm{~h}$, the relative crystallinity sharply increases to $63 \%$. Then, the relative crystallinity gradually increases from $63 \%$ to 93\% with increasing crystallization time from 48 to $120 \mathrm{~h}$.

$\mathrm{N}_{2}$ adsorption-desorption experiments were conducted to investigate the change of the textural properties of the synthesized samples during the crystallization process. The $\mathrm{N}_{2}$ adsorption-desorption isotherms and the pore size distribution curves of the samples synthesized at different crystallization times are shown in Fig. 8. All of the $\mathrm{N}_{2}$ adsorption-adsorption isotherms of the samples crystallized for more than $8 \mathrm{~h}$ have a typical Type IV isotherm, indicating mesoporous structures. The pore size is centered at $4.5 \mathrm{~nm}$. Mesopores with pore di-

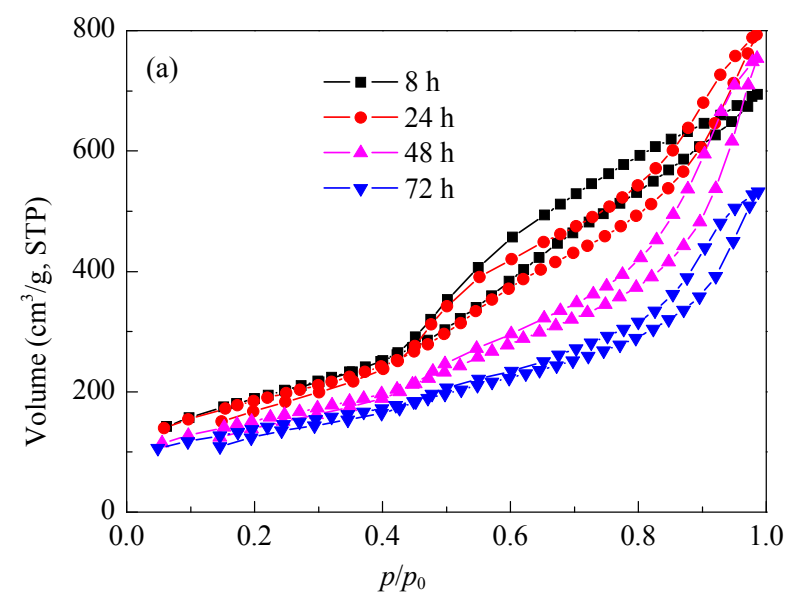

Table 3

Textural properties of samples synthesized for different crystallization times.

\begin{tabular}{lccccccc}
\hline Crystallization & \multicolumn{3}{c}{ Surface area $\left(\mathrm{m}^{2} / \mathrm{g}\right)$} & & \multicolumn{3}{c}{ Pore volume $\left(\mathrm{cm}^{3} / \mathrm{g}\right)$} \\
\cline { 2 - 3 } \cline { 7 - 8 } time $(\mathrm{h})$ & $S_{\text {BET }}$ & $S_{\text {Meso }}$ & $S_{\text {Micro }}$ & & $V_{\text {total }}$ & $V_{\text {Meso }}$ & $V_{\text {Micro }}$ \\
\hline 8 & 690 & 690 & 0 & & 1.07 & 1.07 & 0 \\
24 & 668 & 624 & 44 & & 1.22 & 1.21 & 0.01 \\
48 & 548 & 508 & 40 & & 1.16 & 1.15 & 0.01 \\
72 & 502 & 431 & 71 & & 0.84 & 0.81 & 0.03 \\
\hline
\end{tabular}

ameter greater than $10 \mathrm{~nm}$ are also present. When increasing the crystallization time to $24 \mathrm{~h}$, the synthesized sample is still mostly mesoporous, although a small number of micropores are formed, as indicated in Fig. 8(b) and Table 3. The pore size distribution also changes, and more mesopores of $\sim 20 \mathrm{~nm}$ in diameter are present. As the crystallization time is further increased to 48 and $72 \mathrm{~h}$, the corresponding $\mathrm{N}_{2}$ adsorption-desorption isotherms change and pore size distribution show a remarkable decrease in the number of $\sim 4 \mathrm{~nm}$ diameter mesopores, and an increase in the number of $\sim 30 \mathrm{~nm}$ diameter mesopores.

The textural properties of the samples synthesized for different crystallization times are listed in Table 3. With the generation of the MFI phase in the synthesized samples, the microporous surface area and volume increase while the surface area and pore volume associated with the mesoporous surface decrease. $S_{\text {BET }}$ and $S_{\text {Meso }}$ of the samples decrease with increasing crystallization time while $S_{\text {Micro }}$ tends to increase. The variation of the pore volume shows almost the same trend as that of the surface areas except for the slightly lower total pore volume at 8 h. From the XRD characterizations, both the samples synthesized for 8 and $24 \mathrm{~h}$ are mesoporous. The small difference in the pore volumes indicates that the mesoporosity developed during this period.

To clarify the structural change process of the samples synthesized for different crystallization times, TEM images were obtained. Figure 9 shows the TEM images of the samples synthesized for different crystallization times. As shown in Fig. 9(a), only mesoporous material with an irregular lamellar structure was formed during the initial $8 \mathrm{~h}$, which is in good agreement with the XRD results (Fig. 6(a)). After synthesis for

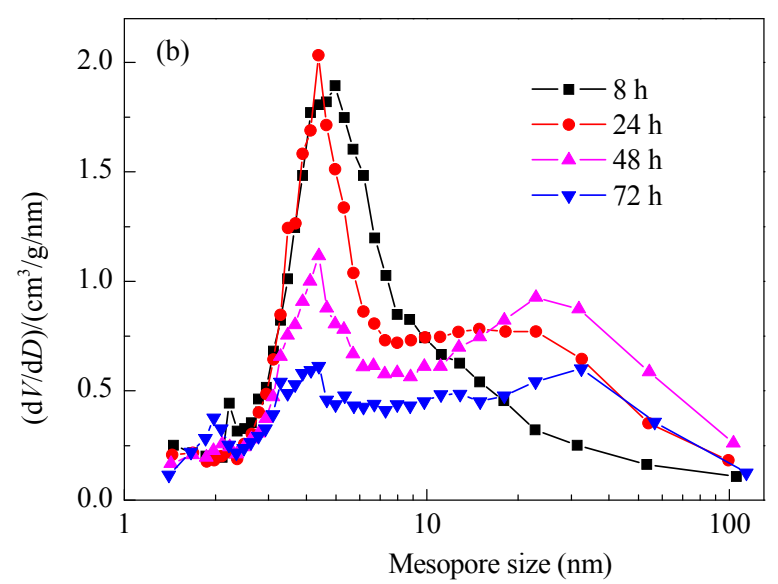

Fig. 8. $\mathrm{N}_{2}$ adsorption-desorption isotherms (a) and pore size distributions (b) of samples synthesized at different crystallization times. 


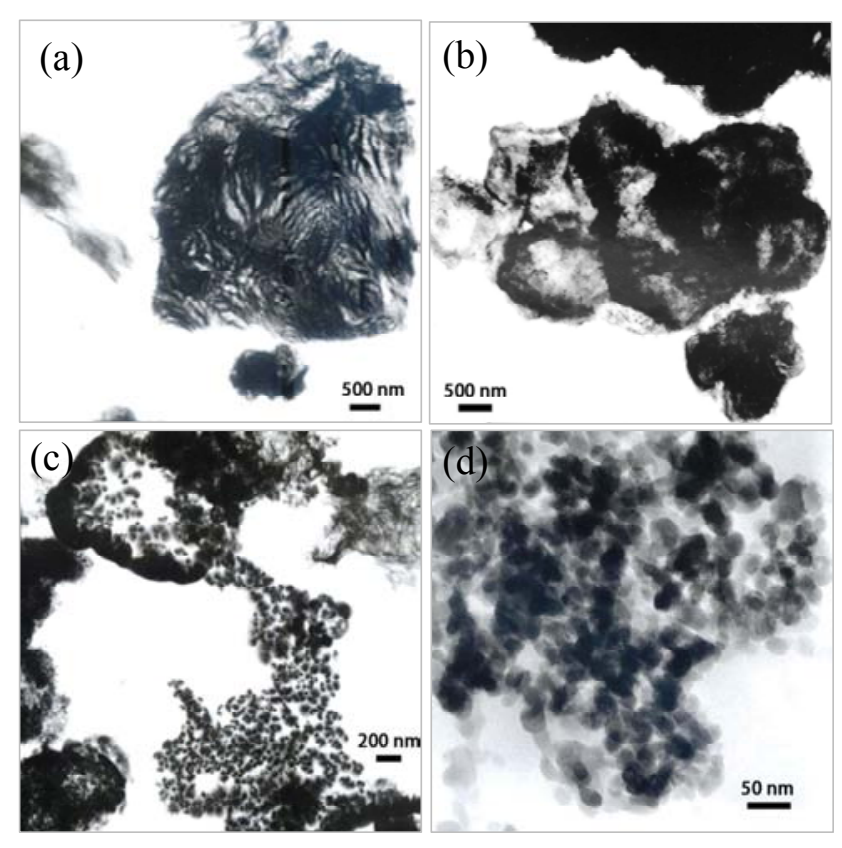

Fig. 9. TEM images of samples synthesized for crystallization times of 8 (a), 24 (b), 48 (c), and $72 \mathrm{~h}(\mathrm{~d})$.

$24 \mathrm{~h}$, the obtained sample still retains the mesoporous phase, as indicated in the XRD pattern, while the corresponding TEM image (Fig. 9(b)) indicates that the sample grows into a hollow structure. This change in the structure confirms the development of mesopores during the synthesis period from 8 to $24 \mathrm{~h}$, which may lead to the difference in pore volume (Table 3). Further increasing the crystallization time to $48 \mathrm{~h}$ leads to a rapid transformation from the mesoporous structure with hollow morphology to the crystalline phase. As shown in Fig. 9(c), a large number of crystals are observed, although the shell part of the hollow structure remains untransformed. Upon heating the synthesis gel for $72 \mathrm{~h}$, there is no amorphous phase and only crystals are observed (Fig. 9(d)). In addition, the ZSM-5 crystals aggregate to form particles, which is consistent with the SEM results.

To obtain more information about the zeolite framework formation and the local coordination environment of $\mathrm{Al}$ species during the synthesis process, ${ }^{27} \mathrm{Al}$ MAS NMR experiments were

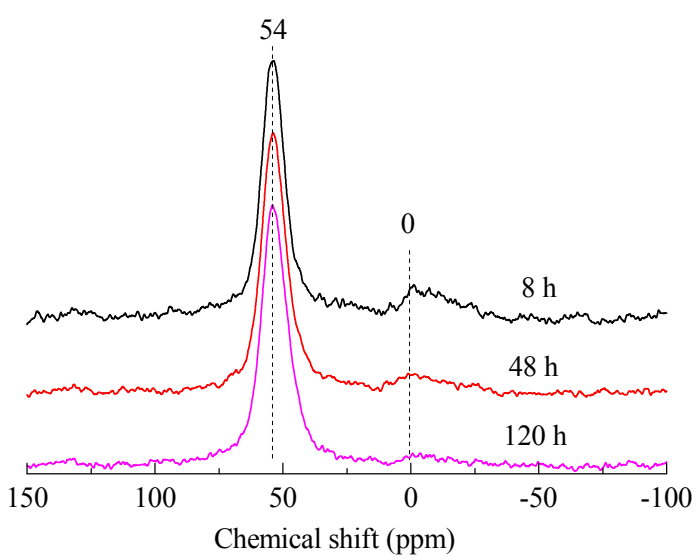

Fig. 10. ${ }^{27} \mathrm{Al}$ MAS NMR spectra of samples synthesized for crystallization times of 8,48 , and $120 \mathrm{~h}$.

conducted. Since the MFI phase was confirmed to form after crystallization for $48 \mathrm{~h}$, only the samples synthesized for 8,48 , and $120 \mathrm{~h}$ were used for the ${ }^{27} \mathrm{Al}$ MAS NMR investigation.

Figure 10 shows the ${ }^{27} \mathrm{Al}$ MAS NMR spectra of samples synthesized for crystallization times of 8,48 , and $120 \mathrm{~h}$. Two peaks are present in the spectra of all three samples. The peak centered at $\sim 54 \mathrm{ppm}$ corresponds to tetrahedral Al of framework $\mathrm{Al}$ species. The other peak, centered at $\sim 0 \mathrm{ppm}$ with lower intensity, is ascribed to octahedral $\mathrm{Al}$, which is normally associated with non-framework Al species. Furthermore, from Fig. 10 , the peaks at $\sim 54 \mathrm{ppm}$ for all three samples have high intensity, which indicates that large amounts of tetrahedral $\mathrm{Al}$ are present in the ZSM-5 framework, even at the early stage of the synthesis $(8 \mathrm{~h})$. Furthermore, the intensity of the peak at $\sim 0$ ppm slowly decreased with the increase of the crystallization time from 8 to $120 \mathrm{~h}$. This indicates that an increasing amount of octahedral $\mathrm{Al}$ in the non-framework $\mathrm{Al}$ species are converted into tetrahedral $\mathrm{Al}$ and located in the framework of the MZSM-5 with increasing crystallization time.

Based on the analysis of the results above, a possible mechanism to explain the formation of MZSM-5 using C18-3-18 as a mesopore directing agent for the crystallization transformation process is shown in Scheme 2. During the early stage (Step I), a

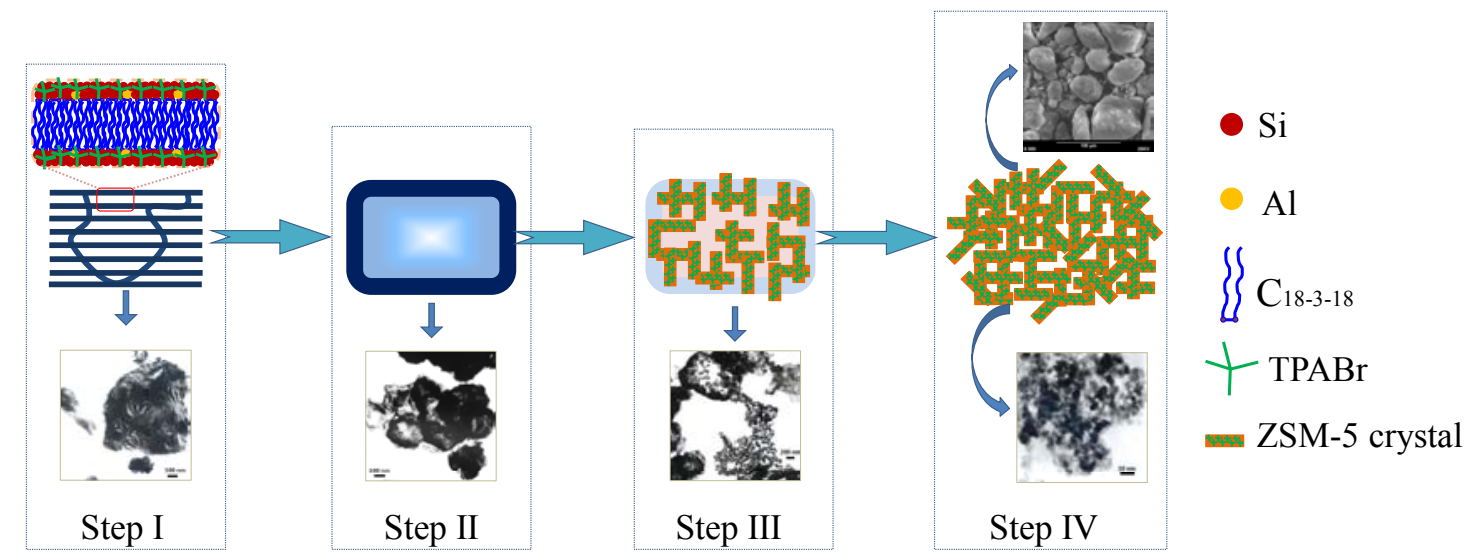

Scheme 2. Proposed formation process for the synthesis of MZSM-5 using $\mathrm{C}_{18-3-18}$ as a mesoporous structure directing agent. 
mesoporous irregular lamellar structure is formed from the starting synthesis gel under the structure directing function of C18-3-18. The mesoporous phase then changes from the irregular lamellar structure to a hollow structure (Step II). As the hydrothermal synthesis proceeds (Step III), the mesoporous hollow structure crystallizes into ZSM-5 crystals (MFI phase) with the involvement of the TPABr microporous template. Finally, the generated ZSM-5 crystals grow and aggregate to form MZSM-5 particles with large diameter mesopores $(>10 \mathrm{~nm})$ between the crystal particles (Step IV), and the initially formed mesopores of $\sim 4 \mathrm{~nm}$ in size are destroyed with crystallization.

\section{Conclusions}

In summary, MZSM-5 with inter-crystalline mesopores was successfully synthesized by a dual-templating hydrothermal method using a new gemini surfactant, $\mathrm{C}_{18-3-18}$, as a mesopore directing agent. This synthesis method was confirmed to be effective at different crystallization temperatures. A low crystallization temperature, such as $130^{\circ} \mathrm{C}$, was better for the synthesis of MZSM-5 with good crystallinity, high mesoporous surface area, high mesoporous volume, and regular morphology. The relatively low crystallization temperature required may originate from the unique $-\mathrm{N}^{+}-\left(\mathrm{CH}_{2}\right)_{3}-\mathrm{N}^{+}$- group of the $\mathrm{C}_{18-3-18}$ mesopore directing agent. The amount of $\mathrm{C}_{18-3-18}$ used in the synthesis affected the relative crystallinity and the textural properties of the obtained MZSM-5. Optimizing the ratio of mesoporous directing agent $\left(\mathrm{C}_{18-3-18}\right)$ to microporous template
(TPABr) ensured the synthesis of MZSM-5. Detailed investigation showed that the formation of MZSM- 5 followed a crystallization transformation process. $\mathrm{C}_{18-3-18}$ caused the formation of mesoporous material during the early stage, which was subsequently converted into MZSM-5 crystals by the function of TPABr as the template for the formation of the MFI phase. As the synthesis proceeded, the MZSM-5 crystals aggregate into particles by weak interactions. $\mathrm{C}_{18-3-18}$ as a mesopore directing agent could be extended to the synthesis of other mesoporous zeolites.

\section{Acknowledgment}

B. L. Su acknowledges the Chinese Central Government for an "Expert of the State" position in the program of "Thousands Talents" and the Chinese Ministry of Education for a Changjiang Scholar position at the Wuhan University of Technology.

\section{References}

[1] Serrano D P, Aguado J, Escola J M, Rodríguez J M, Peral Á. Chem Mater, 2006, 18: 2462

[2] Chal R, Gérardin C, Bulut M, van Donk S. ChemCatChem, 2011, 3: 67

[3] Na K, Choi M, Ryoo R, Micropor Mesopor Mater, 2013, 166: 3

[4] Li X Y, Sun M H, Rooke J C, Chen L H, Sun B L. Chin J Catal (李小云, 孙明慧, Rooke Joanna Claire, 陈丽华, 苏宝连. 催化学报), 2013, 34: 22

[5] Zhang C M, Liu Q, Xu Z, Wang K S. Microporous Mesoporous Mater,

\section{Graphical Abstract}

Chin. J. Catal., 2014, 35: 1727-1739 doi: 10.1016/S1872-2067(14)60128-5

Synthesis of mesoporous ZSM-5 using a new gemini surfactant as a mesopore directing agent: A crystallization transformation process

Quanyi Wang, Yingxu Wei*, Shutao Xu, Mozhi Zhang, Shuanghe Meng, Dong Fan, Yue Qi, Jinzhe Li, Zhengxi Yu, Cuiyu Yuan, Yanli He, Shuliang Xu, Jingrun Chen, Jinbang Wang, Baolian Su *, Zhongmin Liu *

Dalian Institute of Chemical Physics, Chinese Academy of Sciences, China; University of Namur (FUNDP), Belgium;

Wuhan University of Technology, China; University of Chinese Academy of Sciences, China

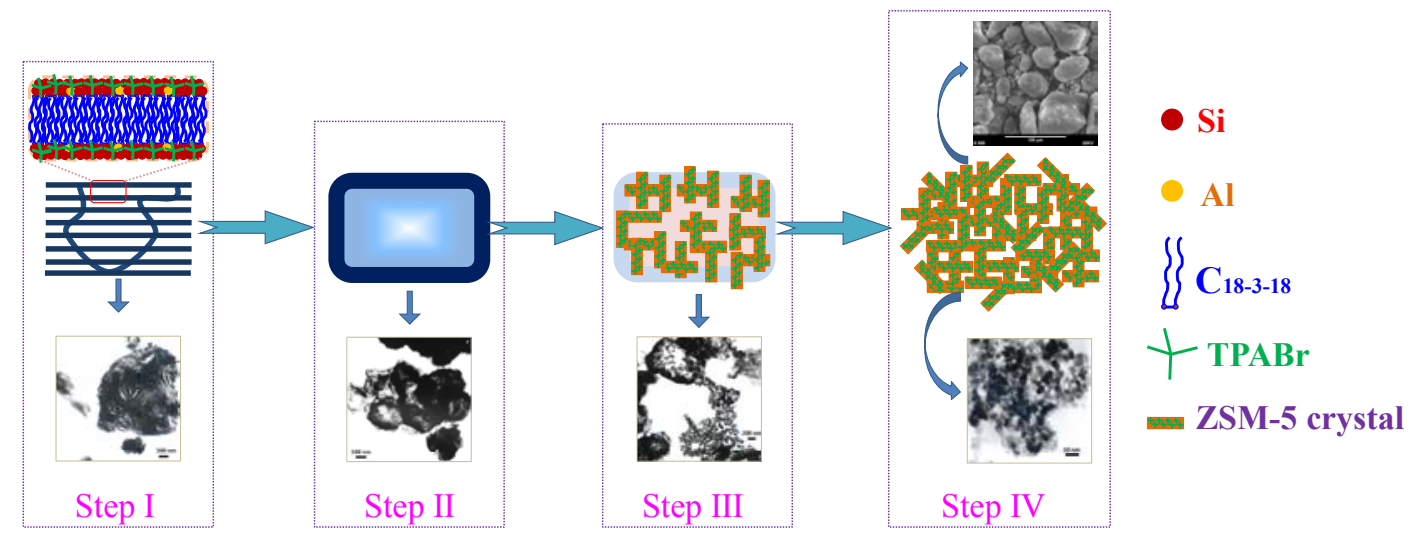

A new gemini surfactant, $\left[\mathrm{C}_{18} \mathrm{H}_{37}\left(\mathrm{CH}_{3}\right)_{2}-\mathrm{N}^{+}-\left(\mathrm{CH}_{2}\right)_{3}-\mathrm{N}^{+}-\left(\mathrm{CH}_{3}\right)_{2} \mathrm{C}_{18} \mathrm{H}_{37}\right] \mathrm{Cl}_{2}\left(\mathrm{C}_{18-3-18}\right)$, has been successfully used to synthesize mesoporous ZSM-5 via a crystallization transformation process. The mesoporous material formed using the $\mathrm{C}_{18-3-18}$ template during the early stage and was subsequently converted into mesoporous ZSM-5 crystals using tetrapropylammonium bromide as the template for the formation of MFI phase. 
2003, 62: 157

[6] Beers A E W, van Bokhoven J A, de Lathouder K M, Kapteijn F, Moulijn J A. J Catal, 2003, 218: 239

[7] Viswanadham N, Kumar M. Microporous Mesoporous Mater, 2006, 92: 31

[8] Song Y M, Ren N, Tang Y. Chin J Catal (宋燕梅, 任楠, 唐䝠. 催化学 报), 2012, 33: 192

[9] Groen J C, Peffer L A A, Moulijn J A, Perez-Ramirez J. Chem Eur J, 2005, 11: 4983

[10] Qi X L, Chen X M, Kong D J, Zheng J L, Yuan X H, Yang D Q. Chin J Catal (祁晓岗, 陈雪梅, 孔德金, 郑均林, 袁小红, 杨德琴. 催化学 报), 2009, 30: 1197

[11] Triantafillidis C S, Vlessidis A G, Evmiridis N P. Ind Eng Chem Res, 2000, 39: 307

[12] Jacobsen C J H, Madsen C, Houzvicka J, Schmidt I, Carlsson A. J Am Chem Soc, 2000, 122: 7116

[13] Tao Y S, Kanoh H, Kaneko K. J Am Chem Soc, 2003, 125: 6044

[14] Zhao J J, Zhou J, Chen Y, He Q J, Ruan M L, Guo L M, Shi J L, Chen H R. J Mater Chem, 2009, 19: 7614

[15] Zhu H B, Liu Z C, Wang Y D, Kong D J, Yuan X H, Xie Z K. Chem Mater, 2008, 20: 1134
[16] Holland B T, Abrams L, Stein A. J Am Chem Soc, 1999, 121: 4308

[17] Zhu Y, Hua Z L, Zhou J, Wang L J, Zhao J J, Gong Y, Wu W, Ruan M L, Shi J L. Chem Eur J, 2011, 17: 14618

[18] Wang Q Y, Xu S T, Chen J R, Wei Y X, Li J Z, Fan D, Yu Z X, Qi Y, He Y L, Xu S L, Yuan C Y, Zhou Y, Wang J B, Zhang M Z, Su B L, Liu Z M. RSC Adv, 2014, 4:21479

[19] Zhou J, Hua Z L, Liu Z C, Wu W, Zhu Y, Shi J L. ACS Catal, 2011, 1: 287

[20] Serrano D P, García R A, Vicente G, Linares M, Procházková D, Čejka J. J Catal, 2011, 279: 366

[21] Song J W, Ren L M, Yin C Y, Ji Y Y, Wu Z F, Li J X, Xiao F S. J Phys Chem C, 2008, 112: 8609

[22] Wang H, Pinnavaia T J. Angew Chem Int Ed, 2006, 45: 7603

[23] Jin J J, Zhang X D, Li Y S, Li H, Wu W, Cui Y L, Chen Q, Li L, Gu J L, Zhao W R, Shi J L. Chem Eur J, 2012, 18: 16549

[24] Choi M, Na K, Kim J, Sakamoto Y, Terasaki O, Ryoo R. Nature, 2009, 461: 246

[25] Na K, Choi M, Park W, Sakamoto Y, Terasaki O, Ryoo R. J Am Chem Soc, 2010, 132: 4169

[26] Na K, Jo C, Kim J, Cho K, Jung J, Seo Y, Messinger R J, Chmelka B F, Ryoo R. Science, 2011, 333: 328

\section{以一种新型Gemini表面活性剂作为介孔模板剂通过转晶过程 合成介孔ZSM-5分子篮}

王全义 ${ }^{\mathrm{a}, \mathrm{b}, \mathrm{e}}$, 魏迎旭 ${ }^{\mathrm{a},{ }^{*}}$, 徐舒涛 ${ }^{\mathrm{a}}$, 张默之 ${ }^{\mathrm{a}, \mathrm{e}}$, 孟霜鹤 ${ }^{\mathrm{a}}$, 㚞 栋 $^{\mathrm{a}, \mathrm{e}}$, 齐 越 ${ }^{\mathrm{a}}$, 李金哲 ${ }^{\mathrm{a}}$, 于政锡 ${ }^{\mathrm{a}}$,

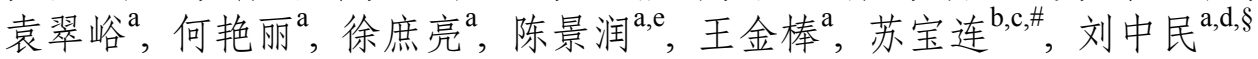

a中国科学院大连化学物理研究所, 洁净能源国家实验室, 辽宁大连 116023

${ }^{b}$ 那慕尔大学无机材料化学实验室, 比利时那慕尔

$\mathrm{c}$ 武汉理工大学材料复合新技术国家重点实验室, 湖北武汉 430070

$\mathrm{d}$ 中国科学院大连化学物理研究所, 催化基础国家重点实验室, 辽宁大连 116023

${ }^{\mathrm{e}}$ 中国科学院大学, 北京 100049

摘要: 将一种新型Gemini表面活性剂, 丙撑基双(十八烷基二甲基氯化铵) $\left[\mathrm{C}_{18} \mathrm{H}_{37}\left(\mathrm{CH}_{3}\right)_{2}-\mathrm{N}^{+}-\left(\mathrm{CH}_{2}\right)_{3}-\mathrm{N}^{+}-\left(\mathrm{CH}_{3}\right)_{2} \mathrm{C}_{18} \mathrm{H}_{37}\right] \mathrm{Cl}_{2}\left(\mathrm{C}_{18-3-18}\right)$, 作为介孔模板剂用于水热法合成介孔ZSM-5分子篮. 结果表明, 在 $130{ }^{\circ} \mathrm{C}$ 低温晶化即可高效合成介孔ZSM-5分子刷. $\mathrm{C}_{18-3-18}$ 的加 入量可影响到所合成介孔ZSM-5分子篮的相对结晶度和织构性质, 它的形成遵从一个转晶过程. 在合成初期, 凝胶中介孔模板剂 $\mathrm{C}_{18-3-18}$ 的使用导向了介孔材料的生成; 随后在TPABr的模板作用下, 介孔材料慢慢转晶生成具有MFI结构的介孔ZSM- 5 ; 然后所 合成的介孔ZSM-5 晶粒进一步长大并聚集形成块状颗粒, 同时产生晶间介孔. $\mathrm{C}_{18-3-18}$ 作为介孔导向剂不仅可用于合成介孔ZSM-5 分子筷, 也可用于其它介孔分子篮的合成中.

关键词: 介孔ZSM-5；双模板法; Gemini型表面活性剂; 晶间介孔; 转晶过程

收稿日期: 2014-04-09. 接受日期：2014-05-28. 出版日期：2014-10-20

*通讯联系人. 电话: (0411)84379335; 传真: (0411)84691570; 电子信箱：weiyx@dicp.ac.cn

\#通讯联系人. 电子信箱: bao-lian.su@unamur.be, baoliansu@whut.edu.cn

通讯联系人. 电话: (0411)84379335; 传真: (0411)84691570; 电子信箱: liuzm@dicp.ac.cn

基金来源：国家自然科学基金(21273230, 21273005, 21103176和21103180).

本文的英文电子版由Elsevier出版社在ScienceDirect上出版(http://www.sciencedirect.com/science/journal/18722067).

\section{1. 前言}

介孔ZSM-5分子篮通常是指同时具有微孔和介孔 孔道的ZSM-5 晶体材料, 它结合单一的微孔和介孔孔道 的优点, 进而增加催化剂活性中心的可接触性、并减少 在应用中的扩散限制, 提高分子篮催化效率 ${ }^{[1-4]}$. 由于其
潜在的应用前景, 介孔ZSM-5分子耖的合成引起了广泛 关注.

迄今为止, 已经提出大量的合成策略用于在传统 ZSM-5分子笁晶体中引入介孔. 研究证明, 高温加热处 理 $^{[5]}$ 、酸处理 ${ }^{[6-8]}$ 、水蒸气热处理 ${ }^{[6,7]}$ 、碱处理 ${ }^{[9,10]}$ 和其它 化学试剂处理 ${ }^{[11]}$ 都是非常有效的在ZSM-5 分子篮晶体 
中创造介孔的手段. 还有研究采用双模板的方法进行晶 化, 即在合成体系中同时含有ZSM-5结构导向剂和介孔 模板剂. 其中, 介孔模板剂可以是硬模板, 包括碳纳米颗 粒或碳纳米管 ${ }^{[12,13]}$ 、聚甲基丙烯酸甲酯(PMMA)纳米 球 ${ }^{[14]}$ 、纳米 $\mathrm{CaCO}_{3}{ }^{[15]}$ 、高分子微球 ${ }^{[16]}$ 等; 也可以是软模

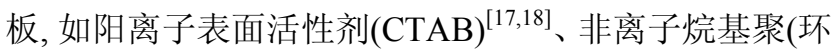
氧乙烷)表面活性剂 ${ }^{[19]}$ 、有机硅烷 ${ }^{[20] 、}$ 阳离子高分子 ${ }^{[21] 、}$ 硅烷化高分子聚合物 ${ }^{[22]}$ 和一些天然产物 ${ }^{[23]}$ 等. 这些介 孔模板剂能够非常有效地在ZSM-5分子篮晶体中产生 介孔, 吸引了众多学者的关注. 近来, Ryoo等 ${ }^{[24-26]}$ 采用 一种具有多头季铵盐基团的有机表面活性剂合成了介 孔ZSM-5 分子篮. 该有机表面活性剂可以同时用作分子 篎的晶体结构导向剂和介孔导向剂. 这是介孔分子篮合 成领域的一个重大进展. 由此可见, 介孔分子篎的新合 成方法的发展和新的表面活性剂的探索依然是等级结 构材料领域的研究重点.

本文采用一种新颖的Gemini型表面活性剂, 丙撑基 双 (十八烷基二甲基氯化铵) $\left[\mathrm{C}_{18} \mathrm{H}_{37}\left(\mathrm{CH}_{3}\right)_{2}-\mathrm{N}^{+}-\right.$ $\left.\left(\mathrm{CH}_{2}\right)_{3}-\mathrm{N}^{+}-\left(\mathrm{CH}_{3}\right)_{2} \mathrm{C}_{18} \mathrm{H}_{37}\right] \mathrm{Cl}_{2}\left(\mathrm{C}_{18-3-18}\right)$, 作为介孔模板剂, 简洁有效地合成了介孔ZSM-5 分子篮. 图式1给出了 $\mathrm{C}_{18-3-18}$ 的结构模型. 据我们所知, 采用 $\mathrm{C}_{18-3-18}$ 作为介孔模 板剂合成介孔ZSM-5分子篮的研究尚未见报道. 在对实 验结果表征和论证的基础上, 对以 $\mathrm{C}_{18-3-18}$ 作为介孔模板 剂的介孔ZSM-5分子篮的形成机理也进行了探讨.

\section{2. 实验部分}

\section{1. 化学试剂和样品的合成}

所有的化学试剂, 包括 $\mathrm{NaAlO}_{2}\left(41 \mathrm{wt} \% \mathrm{Al}_{2} \mathrm{O}_{3}\right)$ 、正 硅酸乙酯 (TEOS, $98.0 \%$, 、四丙基溴化铵 (TPABr, $98.0 \%) 、 \mathrm{NaOH}(96.0 \%)$ 和 $\left(\mathrm{C}_{18-3-18}, 95.0 \%\right)$ 均为商业分析 纯试剂, 且不经纯化直接使用.

以 $\mathrm{C}_{18-3-18}$ 作为介孔模板剂, 采用水热法合成介孔 ZSM-5 分子篮. 起始合成溶液的凝胶比为 $40 \quad \mathrm{SiO}_{2}: 1.0$ $\mathrm{Al}_{2} \mathrm{O}_{3}: 20 \mathrm{NaOH}: 10 \mathrm{TPABr}: x \mathrm{C}_{18-3-18}: 7000 \mathrm{H}_{2} \mathrm{O}$. 水热合成 温度为 $130-175^{\circ} \mathrm{C}$. 具体合成步骤如下: 将 $0.26 \mathrm{~g}$ $\mathrm{NaAlO}_{2}, 0.80 \mathrm{~g} \mathrm{NaOH}, 2.80 \mathrm{~g}$ TPABr溶解到135 g H 在搅拌状态下加入 $8.93 \mathrm{~g}$ TEOS和 $3.33 \mathrm{~g} \mathrm{C}_{18-3-18}(x=4)$, 充分摚拌之后, 合成溶胶移入 $200 \mathrm{~mL}$ 不锈钢合成釜中. 合成釜经密封之后, 移入烘箱, 在摚拌、加热和自生压力 下晶化一定时间. 晶化结束后, 得到的样品经过反复水 洗和离心分离, 最后得到的样品移入烘箱在 $120^{\circ} \mathrm{C}$ 干燥 $12 \mathrm{~h}, 600{ }^{\circ} \mathrm{C}$ 焙烧 $6 \mathrm{~h}$. 其中将在 $150{ }^{\circ} \mathrm{C}$ 晶化 $36 \mathrm{~h}$ 的样品命
名为 MZSM-5-A; 在 $130^{\circ} \mathrm{C}$ 晶化 $120 \mathrm{~h}$ 的样品命名为 MZSM-5-B; 在 $120^{\circ} \mathrm{C}$ 先晶化 $48 \mathrm{~h}$, 再升温到 $175^{\circ} \mathrm{C}$ 晶化 6 $\mathrm{h}$ 的样品命名为MZSM-5-C. 为了比较, 同法制备了传统 的微孔ZSM-5分子篎, 只是没有加介孔模板剂, 在 $175^{\circ} \mathrm{C}$ 晶化48 h制得, 记为ZSM-5.

\section{2. 样品的表征}

采用日本理学 $\mathrm{D} / \mathrm{max}-\mathrm{rb}$ 型X射线衍射(XRD)仪测试 样品的晶相, 测定条件: 室温, $\mathrm{Cu}$ 靶, $K_{\alpha}$ 辐射源 $(\lambda=$ $1.5405 \AA)$, 电压 $40 \mathrm{kV}$, 电流 $40 \mathrm{~mA}$. 根据ZSM-5 分子篮 样品在 $2 \theta=22^{\circ}-25^{\circ}$ 之间五指峰强度确定其相对结晶度.

采用 KYKY-AMRAY-1000B 型扫描电子显微镜 (SEM)观测样品的表面形貌. 采用JEOL JEM-2000Ex型 透射电子显微镜(TEM)来研究催化剂的孔道结构信息.

采用美国Quantachrome公司NOWA4000型物理吸 附仪在 $-196^{\circ} \mathrm{C}$ 对分子篎样品进行 $\mathrm{N}_{2}$ 物理吸附性能表征. 实验前, 样品需在真空条件下 $130^{\circ} \mathrm{C}$ 处理 $1 \mathrm{~h}, 350^{\circ} \mathrm{C}$ 处理 $2 \mathrm{~h}$.

${ }^{27} \mathrm{Al}$ 固体核磁共振(NMR)实验在Bruker Avance III 600 型核磁共振波谱仪上进行. ${ }^{27} \mathrm{Al}$ MASNMR谱图是在 $4 \mathrm{~mm}$ 三共振探头进行, ${ }^{27} \mathrm{Al}$ 的共振频率为 $156.4 \mathrm{MHz}$, 采 用 $\pi / 8$ 脉冲宽度为 $0.75 \mu \mathrm{s}$ 和 $2 \mathrm{~s}$ 的弛豫延迟, 转速为 12 $\mathrm{kHz}$, 累加 100 次. ${ }^{27} \mathrm{Al}$ 的化学位移以 $\mathrm{NH}_{4} \mathrm{Al}\left(\mathrm{SO}_{4}\right)_{2} \cdot 12 \mathrm{H}_{2} \mathrm{O}$ 为二次参考外标 $\left(\delta_{\mathrm{Al}}=-0.4 \mathrm{ppm}\right)$.

\section{3. 结果与讨论}

\section{1. 在不同晶化温度下的合成}

图 1 为不同晶化温度下所合成介孔ZSM-5和微孔 ZSM-5 样品的XRD谱. 由图可见, 所有样品均呈现出 MFI的典型结构, 且再无其它杂相的峰生成. 还可以看 出, 尽管起始凝胶比和所采用的双模板剂完全一样, 但 不同晶化温度所制介孔ZSM-5 分子篮的相对结晶度略 有差异, 其中在 $150^{\circ} \mathrm{C}$ 晶化 $36 \mathrm{~h}$ 得到的MZSM-5-A和先在 $120^{\circ} \mathrm{C}$ 晶化 $48 \mathrm{~h}$, 后 $175^{\circ} \mathrm{C}$ 晶化 $6 \mathrm{~h}$ 得到的MZSM-5-C具有 低的相对结晶度, 而在 $130^{\circ} \mathrm{C}$ 晶化 $120 \mathrm{~h}$ 得到的 MZSM-5-B相对结晶度最高, 接近于传统ZSM-5 分子篮. 这表明MZSM-5-B的晶化条件 $\left(130^{\circ} \mathrm{C}, 120 \mathrm{~h}\right)$ 更为适宜.

图2为传统ZSM-5和各介孔ZSM-5的 $\mathrm{N}_{2}$ 吸附-脱附等 温线和相应的孔分布曲线. 孔分布曲线是通过BJH模型, 采用吸附分支计算得到. 表1列出了它们的织构性质. 如图2(a)所示, 传统ZSM-5分子篎的 $\mathrm{N}_{2}$ 吸附-脱附曲线为 典型的I型(Langmuir), 其 $\mathrm{N}_{2}$ 吸附量在吸附相对压力较高 时没有明显增加, 且没有吸附滞后环. 这些都是无介孔 
的微孔沸石分子篎的典型特征. 如图 2(b) 所示, 传统 ZSM-5分子篮不含有介孔( $2 \mathrm{~nm}$ 以上); 其总比表面积和 总孔体积分别为 $328 \mathrm{~m}^{2} / \mathrm{g}$ 和 $0.16 \mathrm{~cm}^{3} / \mathrm{g}$ (表1), 但其中介 孔比表面积和介孔孔体积分别仅为 $59 \mathrm{~m}^{2} / \mathrm{g}$ 和 $0.03 \mathrm{~cm}^{3} / \mathrm{g}$.

介孔ZSM-5 分子篎样品的 $\mathrm{N}_{2}$ 吸附-脱附曲线明显不 同于传统ZSM-5 分子篎, 呈现出I型和IV型复合形状的曲 线. 这表明在采用双模板法在不同晶化温度下合成的样 品同时存在着微孔和介孔. 另外, 由于介孔的产生, 使得 这三个介孔ZSM-5 分子篮样品的 $\mathrm{N}_{2}$ 吸附量在相对压力 较高吸附时急剧增加, 并形成吸附滞后环, 这证实了介 孔的产生. 随着介孔的产生, MZSM-5-A, MZSM-5-B和 MZSM-5-C的介孔比表面积分别增加到 133, 268 和 141 $\mathrm{m}^{2} / \mathrm{g}$, 相应的介孔体积则分别增加到 $0.49,0.66$ 和 0.32 $\mathrm{cm}^{3} / \mathrm{g}$ (表1). 同时, 它们的微孔比表面积分别降低到 121 , 150 和 $138 \mathrm{~m}^{2} / \mathrm{g}$, 相应的微孔体积则分别降低到 $0.06,0.07$ 和 $0.06 \mathrm{~cm}^{3} / \mathrm{g}$. 如图2(b)所示, 介孔ZSM-5分子篮的孔分 布曲线较宽, 位于 $2-100 \mathrm{~nm}$, 表明所产生的介孔可能是 来自于晶间孔, 其中MZSM-5-A和MZSM-5-C的介孔大 部分位于 $50 \mathrm{~nm}$ 左右, 而MZSM-5-B中50 nm左右的介孔 比例明显降低, 在 2-10 $\mathrm{nm}$ 之间的介孔大大增加.

图3为传统ZSM-5和各介孔ZSM-5分子篮的代表性 SEM照片. 由图可见, 传统ZSM-5 分子篮为 0.6-1 $\mu \mathrm{m}$ 的 晶体颗粒; $150^{\circ} \mathrm{C}$ 晶化 $36 \mathrm{~h}$ 所得到的样品MZSM-5-A也 呈现出颗粒大小不均一的晶体. 稍微大一点的晶粒约为 $10 \mu \mathrm{m}$, 是由 $1 \mu \mathrm{m}$ 的小晶体颗粒聚集而成的. 图3(e)给 出了低倍率的 MZSM-5-B 的 SEM 照片. 可以看出, MZSM-5-B为尺寸大小不均一的块状颗粒. 从放大的图 3(f) 可见, 尺寸大小不均一的块状颗粒是由很多小的 ZSM-5 的晶粒聚集而成的, 由此产生了晶粒间的介孔. 这与 $\mathrm{N}_{2}$ 物理吸附结果一致. 相应地, MZSM-5-C样品与 MZSM-5-A和MZSM-5-B的类似, 也呈现出尺寸大小不 均一的块状颗粒. 这些颗粒也都是由小的ZSM- 5 晶粒聚 集而成. 在三个微孔-介孔复合ZSM-5分子篮样品中, MZSM-5-B具有相对较为规整的形貌. 这也说明在使用 $\mathrm{C}_{\text {18-3-18 }}$ 作为介孔模板剂时, 相对低温的晶化合成路线更 有利于介孔ZSM-5的合成.

综上可见, 不同的晶化温度会影响最终得到的介孔 ZSM-5 分子篮的形貌、比表面积和孔结构, 相对较低的 晶化温度 $\left(130^{\circ} \mathrm{C}\right)$ 比较适宜, 在该温度下晶化 $120 \mathrm{~h}$ 合成 的样品具有较高的结晶度、介孔比表面积和介孔孔体积 以及较为规整的形貌. 使用 $\mathrm{C}_{18-3-18}$ 作为介孔模板剂可以 在较低的温度 $\left(130{ }^{\circ} \mathrm{C}\right)$ 下实现介孔ZSM-5 分子篮的合成,
这可能是由于 $\mathrm{Gemini}$ 型表面活性剂 $\mathrm{C}_{18-3-18}$ 中独特的 $-\mathrm{N}^{+}-\left(\mathrm{CH}_{2}\right)_{3}-\mathrm{N}^{+}-$基团造成的. 在低温下, 这种独特的基 团结构的存在加速分子篮晶化的原因仍需进一步研究.

\section{2. $\mathrm{C}_{18-3-18}$ 用量的影响}

在水热合成中, 介孔模板剂的加入量常常可影响最 终得到的介孔ZSM-5分子篮的结晶度、形貌和相关的比 表面积和介孔孔道结构. 因此, 本文考察了 $\mathrm{C}_{18-3-18}$ 的使 用量对介孔ZSM-5分子篮合成的影响, 所采用的合成条 件为 $130{ }^{\circ} \mathrm{C}$ 水热晶化 $96 \mathrm{~h}$, 起始合成凝胶的摩尔比为 40 $\mathrm{SiO}_{2}: 1.0 \quad \mathrm{Al}_{2} \mathrm{O}_{3}: 20 \mathrm{NaOH}: 10$ TPABr: $x \mathrm{C}_{18-3-18}: 7000 \mathrm{H}_{2} \mathrm{O}$, 其中 $x$ 代表 $\mathrm{C}_{18-3-18}$ 的加入量.

图4为使用不同量的介孔模板剂 $\mathrm{C}_{18-3-18}$ 合成的介孔 ZSM-5 分子篎样品的XRD谱. 由图可见, 各样品均呈现 出MFI独特的拓扑结构, 且无其它物相的峰. 当 $\mathrm{C}_{18-3-18}$ 的 使用量 $x=2$ 和 4 时, 所得分子篮样品的相对结晶度接近; 至6时则略有升高, $x$ 增至 8 时, 所得分子篮样品的相对结 晶度急剧下降. 这是在使用双模板法合成微孔-介孔复 合分子篎时的正常现象. 在通常的水热合成体系下, 所 采用的双模板体系, 即微孔模板剂TPABr和介孔结构导 向剂 $\mathrm{C}_{18-3-18}$, 在合成过程中是以一种相互竞争、而不是协 同合作的方式在发挥作用. 如果在水热合成体系加入过 多介孔模板剂 $\mathrm{C}_{18-3-18}, \mathrm{TPABr}$ 和 $\mathrm{C}_{18-3-18}$ 的竞争作用较强, 导致MFI晶相的形成速度比较慢, 即降低了ZSM-5生成 的速度, 使得合成体系中大量的合成凝胶未能及时转变 成ZSM-5, 而以无定形的状态保留了下来, 因而所得样 品的相对结晶度大大降低.

图5为上述介孔ZSM-5 分子篮样品的 $\mathrm{N}_{2}$ 吸附-脱附等 温线和孔分布曲线, 相应的织构性质列于表2. 可以看 到, 所有样品的 $\mathrm{N}_{2}$ 吸附-脱附等温线均为 I 型和IV型复合 形状, 表明同时存在着微孔和介孔. 如表2所示, 随着介 孔模板剂加入量 $x$ 依次增加到 2,4 和 6, 所合成的介孔 ZSM-5 分子篮的比表面积(包括微孔比表面积和介孔比 表面积)相应增至 325,491 和 $515 \mathrm{~m}^{2} / \mathrm{g}$, 其中 $x=4$ 时的总 孔体积 $V_{\text {total }}\left(0.82 \mathrm{~cm}^{3} / \mathrm{g}\right)$ 要大于样品 $x=2\left(0.52 \mathrm{~cm}^{3} / \mathrm{g}\right)$ 和 $x$ $=6\left(0.66 \mathrm{~cm}^{3} / \mathrm{g}\right)$. 这表明该样品含有较为丰富的介孔. 而 $x=6$ 时的样品相对较低的总孔体积很可能因为其中 的微孔更多. $x$ 进一步增至 8 , 所得样品的比表面积和孔 体积可达最高. 然而考虑到其较低的相对结晶度和较小 的微孔比表面积, $\mathrm{C}_{18-3-18}$ 的使用量太大并不利于介孔 ZSM-5 分子篮的生成.

上述结果表明, 在合成凝胶中加入不同量的介孔模 板剂 $\mathrm{C}_{18-3-18}$, 可以影响到生成的介孔ZSM-5 分子篮的相 
对结晶度、比表面积和孔体积等性质. 总体而言, $\mathrm{C}_{18-3-18}$ 加入量 $x=4$ 和 6 相对较好.

如图 5(b) 所示, 当 $\mathrm{C}_{18-3-18}$ 加入量 $x=2,4$ 和 6时, 所得 ZSM-5 分子篮介孔分布较宽, 位于 $2-30 \mathrm{~nm}$, 至 $x=8$ 时, 所得样品的介孔集中于 $4 \mathrm{~nm}$.

\section{3. 介孔ZSM-5分子篮的形成过程}

为了阐明介孔ZSM-5 分子篮的形成过程, 我们选用 介孔模板剂 $\mathrm{C}_{18-3-18}$ 的用量 $x=4$, 于 $130{ }^{\circ} \mathrm{C}$ 分别晶化 8,24 , $48,72,96$ 和 $120 \mathrm{~h}$ 来观察微孔和介孔的产生和变化趋势, 其中, $t=96$ 和 $120 \mathrm{~h}$ 时所得样品分别为 3.2 节中的样品 $(x$ =4)和3.1节中的MZSM-5-B. 相应的表征在各节中已经 分别给出. 在这里仅选用这六点的相对结晶度绘制晶化 曲线.

图6为不同晶化时间所得样品的小角和广角XRD 谱. 由图可见, 当晶化至 8 和 $24 \mathrm{~h}$ 时, 所得样品在广角 $\mathrm{XRD}$ 谱中没有衍射峰, 但在小角XRD谱中存在一个衍射 峰, 表明它们均为介孔材料. 当晶化超过 $24 \mathrm{~h}$ 时, 样品中 仅出现MFI结构. 这也说明在 $130^{\circ} \mathrm{C}$ 水热合成ZSM-5具 有缓慢晶化的特征. 即采用 $\mathrm{C}_{18-3-18}$ 作为介孔模板剂在 $130^{\circ} \mathrm{C}$ 水热合成ZSM-5 的初期, 需要一个诱导期来诱导 晶化的发生. 当进行到 $48 \mathrm{~h}$ 时, 所合成样品的ZSM-5 峰 型非常明显, 至7 $2 \mathrm{~h}$ 时, 所得样品的ZSM-5 峰强度进一步 增加.

图7为微孔-介孔ZSM-5分子篮的晶化曲线, 它是基 于不同晶化时间所得样品的相对结晶度而得. 在相对结 晶度的计算中, 以传统ZSM-5样品为基准, 将其相对结 晶度定义为 $100 \%$. 如图7所示, 在使用介孔模板剂 $\mathrm{C}_{18-3-18}$ 进行合成的初期 $(24 \mathrm{~h})$, 并未生成ZSM-5 相, 是一个诱导 阶段. 当晶化时间持续到 $48 \mathrm{~h}, \mathrm{ZSM}-5$ 相开始形成, 所得 样品的相对结晶度快速升至 $63 \%$; 至 $72 \mathrm{~h}$ 时为 $79 \%, 96 \mathrm{~h}$ 时达 $90 \%$. 当晶化时间为 $120 \mathrm{~h}$ 时, 所得样品的相对结晶 度达到了 $93 \%$.

图 8 为不同晶化时间所得样品的 $\mathrm{N}_{2}$ 吸附-脱附等温 线和孔分布曲线. 可以看出, 晶化 $8 \mathrm{~h}$ 所得样品的吸附脱 附等温线为典型的IV型, 表明存在介孔, 其孔径大部分 分布在 $4.5 \mathrm{~nm}$, 也有部分孔径大于 $10 \mathrm{~nm}$. 当晶化时间延 长到 $24 \mathrm{~h}$, 所得样品依然是介孔材料, 但已出现少量的微 孔(表3); 另外, 它还存在 $20 \mathrm{~nm}$ 左右的介孔. 当晶化至 48 和 $72 \mathrm{~h}$, 所得样品的 $\mathrm{N}_{2}$ 吸附-脱附等温线继续发生改变, 相应地, $4 \mathrm{~nm}$ 的介孔的比例减少, 而 $30 \mathrm{~nm}$ 介孔比例增 加.

如表3所示, 随着样品中MFI相的生成, 样品的微孔
比表面积和微孔孔体积增加, 介孔比表面积和介孔孔体 积减少. 随着晶化时间的延长, 所得样品的 $S_{\mathrm{BET}}$ 和 $S_{\mathrm{Meso}}$

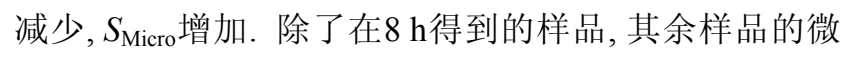
孔和介孔部分的孔体积也呈现出类似的变化趋势. 在晶 化 $8 \mathrm{~h}$ 所得样品的总孔体积 $V_{\text {total }}$ 略低于晶化 $24 \mathrm{~h}$ 时的样 品. 由XRD结果可知, 晶化 8 和 $24 \mathrm{~h}$ 所得的样品都是介孔 材料, 其孔体积的差异暗示了当晶化时间从 $8 \mathrm{~h}$ 进行到 24 $\mathrm{h}$ 时, 样品的介孔孔道结构可能发生了改变.

为了进一步弄清楚介孔ZSM-5 分子篎晶化过程中 样品孔道结构的转变, 采用TEM对上述样品进行表征. 如图9(a)所示, 在晶化初期(前 $8 \mathrm{~h}$ ), 所得样品具有不规则 海绵状介孔孔道, 与XRD结果一致; 至 $24 \mathrm{~h}$ 时, 所得样品 依然是介孔材料(图6和图8), 但形貌发生了转变, 即变成 了一个空心结构的介孔材料. 这可能是晶化 $8 \mathrm{~h}$ 得到的 样品的总孔体积 $V_{\text {total }}$ 低于晶化 $24 \mathrm{~h}$ (图9(b)) 的原因. 当 晶化时间延长到 $48 \mathrm{~h}$, 样品从空心结构转变为MFI结晶 相(图9(c)), 尽管空心结构的壳层部分还没有完全转化, 但有大量的ZSM-5 晶体在空心结构的内部生成. 继续增 加晶化时间到 $72 \mathrm{~h}$, 无定形相完全转化, 只观测到大量的 ZSM-5 晶体颗粒(图9(d)). 之后, ZSM-5 晶粒聚集成大块 颗粒, 与SEM结果一致.

为了更好地研究介孔ZSM-5 分子篮晶化过程中骨 架的形成和 $\mathrm{Al}$ 物种化学配位环境的改变, 本文采用 ${ }^{27} \mathrm{Al}$ MAS NMR对上述样品进行了表征. 综上可见, 晶化达 $48 \mathrm{~h}$ 时, MFI相开始形成. 因此, 选用晶化时间 $t=8,48$ 和 $120 \mathrm{~h}$ 的样品来进行 ${ }^{27} \mathrm{Al}$ MAS NMR对比实验, 结果见图 10. 由图可见, 所有样品均呈现两个峰. 其中位于 54 ppm处的峰可归属于四配位 $\mathrm{Al}$, 也就是分子篮骨架铝引 起的; 另外一个强度较弱的峰出现在 $\sim 0 \mathrm{ppm}$, 通常归属 为八面体 $\mathrm{Al}$, 是分子篮非骨架铝的信号峰. 还可以看出, 这三个样品在 $\sim 54 \mathrm{ppm}$ 的峰都具有很高的强度, 表明在 合成的初始阶段 $(t=8 \mathrm{~h})$, 就已经有大量的四配位铝生 成. 由此可见, 在给定的合成条件下, 四配位铝的生成速 度很快. 同时, 随着晶化时间从 $8 \mathrm{~h}$ 延长到 $120 \mathrm{~h}$, 三个样 品在 $\sim 0 \mathrm{ppm}$ 的峰强度逐渐减弱, 八配位 $\mathrm{Al} 1$ 转变为四配位 $\mathrm{Al}$, 即从非骨架 $\mathrm{Al}$ 转变成骨架 $\mathrm{Al}$. 这与前文结果一致.

综上可以认为, 使用介孔模板剂 $\mathrm{C}_{18-3-18}$ 合成介孔 ZSM-5 分子篮的过程是一个转晶过程. 其示意图见图式 2. 步骤I: 在合成初期阶段, 在介孔模板剂 $\mathrm{C}_{18-3-18}$ 的结构 导向作用下形成了具有不规则海绵状孔道结构的介孔 材料; 该材料的孔径约为 $4 \mathrm{~nm}$. 步骤II: 随着合成时间 的继续, 介孔相被保留, 但其已经从海绵状转变为中空 
状. 步骤III: 随着水热合成过程的进行, 中空的介孔结 构在 TPABr的导向作用下开始晶化, 转变为 MFI相的 ZSM-5 晶粒. 所产生的ZSM-5 晶粒是从中空的介孔结构 的内部开始产生. 随着合成的继续进行, 在步骤 IV, 所产 生的ZSM-5 晶粒进一步长大, 并由于聚集开始形成块状 颗粒. 聚集的ZSM-5 颗粒之间产生 30 nm 的晶间孔，原 来4 nm的介孔因晶化过程的发生而被破坏.

\section{4. 结论}

采用一种新型 $G e m i n i$ 表面活性剂 $\mathrm{C}_{18-3-18}$ 作为介孔导 向剂, 使用双模板水热法成功合成出具有晶体间介孔的 微孔-介孔复合ZSM-5分子篮. 结果表明, 该模板剂对于 微孔-介孔复合ZSM-5 分子篮的合成在 $130-175^{\circ} \mathrm{C}$ 温度 范围内都有效, 相对低的晶化温度 $\left(130^{\circ} \mathrm{C}\right)$ 较为适宜, 所 合成的样品具有较好的相对结晶度、较高的介孔比表面 积、介孔孔体积和较为规整产物形貌。介孔模板剂
$\mathrm{C}_{18-3-18}$ 中独特的 $-\mathrm{N}^{+}-\left(\mathrm{CH}_{2}\right)_{3}-\mathrm{N}^{+}$-基团可能是在较低的晶 化温度下实现介孔ZSM-5合成的原因. 合成凝胶中介孔 模板剂 $\mathrm{C}_{18-3-18}$ 的加入量将影响所制微孔-介孔复合 ZSM-5分子篮的相对结晶度和孔结构性质. 优化的介孔 模板剂与MFI相结构模板剂的比例确保了介孔ZSM-5分 子䇻的合成. 深入的研究表明, 使用 $\mathrm{C}_{18-3-18}$ 和 TPABr合 成介孔ZSM-5 分子篎是一个转晶过程. 在合成初期阶 段, 在介孔模板剂 $\mathrm{C}_{18-3-18}$ 的结构导向作用下形成介孔材 料; 此后, 形成的介孔结构在 TPABr的导向作用下开始 晶化, 转变为 MFI相的ZSM-5 晶粒; 随后进一步长大并 聚集形成块状颗粒并产生晶间介孔. $\mathrm{C}_{18-3-18}$ 作为介孔导 向剂也可能应用于其它介孔分子篎的合成中.

致谢 苏宝连教授特别感谢中国政府给予的首批国家“千 人计划”特聘专家职位, 特别感谢中国教育部给予的在武汉 理工大学的长江学者讲座教授职位. 